\title{
Based Industrial Design Faculty Building "Sharing" Mechanism Study
}

\author{
Zeng Yihui,Yao Shi, Xiong Zhangyuan, Zhang Yaqing, Ma Hui, Wang Shixiong \\ Anhui Wonder University of Information Engineering, Heifei, China, 231201
}

\begin{abstract}
The problems in industry design faculties at the existing Tertiary Education Institutes include: practice lags far behind theory, interaction lacks between faculties and real markets; insufficient supply and instability in higher research faculties. Therefore, this thesis is to introduce a new development model, focusing on "Sharing", for industry design faculties. This model would aims to collaborate resources from the various aspects, including faculties, social projects, teaching staff and internship base. It would target on improving the overall level of theoretical and practical teachings by creating a brand new "Sharing" database. We believe that the quality of industry design faculties would be effectively developed by the cooperation of the "Sharing" platform with effective policies and strategies.
\end{abstract}

KEYWORD: Industry; Teaching staff; Sharing mechanism

\section{GENERAL INSTRUCTIONS}

'Research Report of Anhui's economic development in 2012'pointed out that the government will speed up upgrading of the industrial structure and promote green economy, especially the new industrial of high technology, developing Anhui province through science and education and improving our innovative capacity. In above, it is important to cultivate the high-quality talents who are innovation, applied, interdisciplinary in the field of Industrial Design in this situation. However, there's a critical situation that our province is short on these specialized talents, according to the extensive research of experts in our group. As we known, college is the main position to cultivate these talents, and the school is mainly rely on a number of excellent, professional teachers, those who lay foundations for the school development and accumulate resources. In summary, the way to promote discipline construction, cultivating talents and driving the longterm future of college is to develop a number of high-quality group of outstanding teachers. Training the students to become a senior designer in our field, based on product description, visual communication design as a supplement industrial product design, having basic theory and practical abilities is the main objective of industrial design. The key to achieve the goal is to develop a teachers'group of rational construction. This paper discusses how to develop this kind of teachers'group, in the view of the fact that there are many problems in developing teachers'group in most of the private college.

\section{ANALYSIS OF THE EXISTING PROBLEMS OF INDUSTRIAL DESIGNER TEAM}

Our industrial design professional teachers have 11 people, 6 degrees, 8 master, doctor 1 , including 2 professors, 2 associate professors, 5 lecturers, 2 assistants, "double teacher type" accounted for only 3 of the people. Based on the investigation and analysis of peer industrial design teaching team members of the project group and combined with the present situation of teachers in our school, there are some problems in the age structure, academic structure, professional title structure and the ability of practice and so on, concrete analysis is as follows:

\subsection{Theory is strong than practice, market interaction design with teachers is weak}

Industrial design is an highly integrated interdisciplinary art innovation and engineering disciplines .It combines the scientific sense of emotion and art, it is the creative design activity set function, technology and art, With a high degree of art and Science. [1] This feature requires that teachers have the professional theory knowledge at the same time, also have the ability to grasp the current high-tech mainstream. The domestic 
industrial design professional college courses can be divided into professional courses, professional courses and professional practice teaching. In different schools, the nature of industrial design is not the same, divided into the art of industrial design and Engineering Industrial Design. The main tendency of art industrial design is theory, the engineering are tendency practice, both are not well together. Engineering industrial design in our college is belongs to the industrial design, this requires teachers to have a strong practical ability. With the development of social economy and technology, and the constantly updated of design materials and design thinking. Teachers in Colleges and universities due to the busy teaching and professional title promotion are long out of design practice. The design concept for many teachers is relatively old, failed to update their ideas, the teaching method is old. Part of the industrial design professional teachers have high theoretical level, but the practice is weak, design products without market testing, no application value. The young teacher is often from school to school, they are lack of market understanding and design experience, the opportunity for teachers and students to participate in social project is little, causes the teacher and market interaction design is weak [2]. Therefore, if the teacher is not in the enterprise, understand the market, will affect the goal of cultivating industrial design talents.

\subsection{The low proportion of research teachers}

If private colleges and universities want to develop and improve their own quality, they must introduce and train a group of teachers, and the long-term development of teachers should rely on schools and teachers themselves to learning research and development, only by constantly developing and introducing the research teacher, to the development of private schools [3-4]. The teachers who only teaching and does not participate in the scientific research, the teaching is superficial, the teaching level will be remain stagnant, the classroom will be dull. The proportion of research teacher in our college is very low, seriously affect the training of industrial design professional research and innovation talents.

\subsection{Teachers are not stable, high mobility}

For teachers of Private colleges, the best applicants are employed, and signed termly labor contract with those teachers. Besides that, some people have bias against private colleges in the community ${ }^{[5]}$. Though young industrial design teachers have high degree, due to the reason that low social identity, low professional titles, low salaries and have a larger income gap compared with other industrial design workers, they faced great economic pressures . These young people are used and managed by collage, but those institutions are lack of humane care, causing some teachers job satisfaction is low, and can not find a sense of belonging. Part of the design professional teachers just want to earn more and more school classes pay; another part of the young teachers only get the basic wage, mainly concentrate on the development of a second job or part-time outside school to earn money; the other teachers who have the ability find another job with higher pay after got rich teaching experiences. Teacher's team of design faculty have more unstable phenomenon than other industry professionals teachers. Greater mobility, continuity of teaching, the students thought the stability of certain adverse effects are produced.

\section{THE INDUSTRIAL DESIGN TEACHING STAFF CONSTRUCTION MODE BASED ON THE "SHARING" MECHANISM}

How to effectively address the problem of the existence of the teaching staff of Industrial Design ?Faced with three outstanding issues "theory is superior to practice, the interactive design of teachers and markets is weak", "the proportion of the research-oriented teachers is lower ", " teaching staff is not stable and the mobility is large" and so on, the main reason for the existence of these problems is our industrial design veteran teachers and new teachers, teachers and the community, teachers and students are disjointed. According to our University's industrial design characteristics and existing problems, task group members put forward "sharing" as the core of the industrial design teaching staff construction mode, which is shown in Figure 1, the core idea of the model is "sharing", the universities, community projects, resources, teachers and internship training base for sharing, increase the level of industrial design theory and practice of teachers as a whole, and carefully build a shared interactive platform.

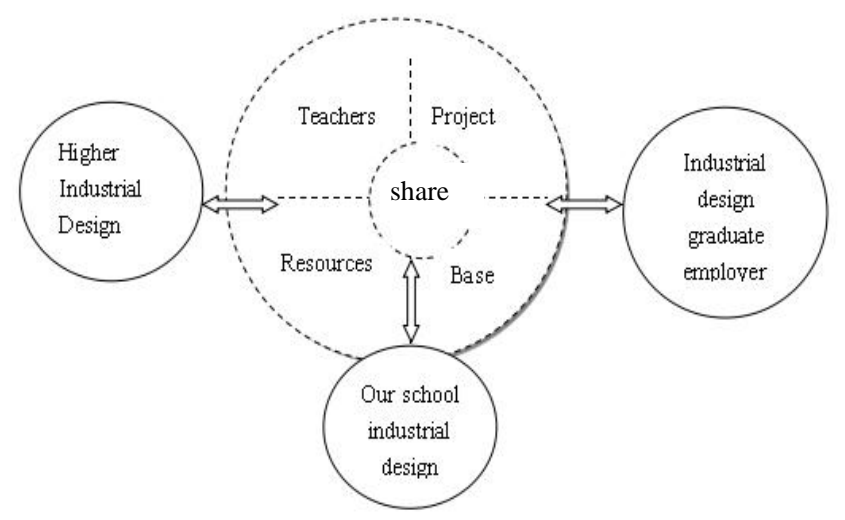

Figure 1 The Industrial Design teaching staff construction mode based on the "sharing" mechanism 


\subsection{The main contents of sharing}

Building an industrial design teaching staff which is of excellence and reasonable structure and is not only understand the theory and also understands the technology, it will need to up and share various resources of industrial design schools and community. Schools and community to unite to form a shared platform and mechanism to supply teachers to learn, collaborate and improve, the only way to ensure long-term development of the teaching staff's teaching faculty, practical ability and collaboration capabilities. The main contents of sharing: teachers of industrial design: including the well-known design teachers in China, teachers of industrial design in the colleges in the city and outstanding design engineers and other experts in the business in the city, etc. ; resources: including teaching materials of industrial design, design works, the models and design achievements of the industrial design Company, etc.; projects: including the crosswise project of school-enterprise cooperation and the vertical project of school has declared; bases: including internship base, training base, company internship training base and school internship training base, etc.

\subsection{The forms of sharing}

\subsubsection{The sharing of network platform}

Schools make a network platform for industrial design, and will make a variety of resources focus on the web, ready for students and teachers to share learning and encourage teachers to log onto the network platform to learn. Teachers can online lecture, answer, check of work, and can also perform teacher-student interactions such as guidance graduation design and so on. Teachers can log onto the network to view outstanding teachers' video resources, teaching skills, process of practice, industrial design works, dynamics of excellent companies and the mainstream thinking of design.

\subsubsection{The sharing of entities}

The sharing of teachers: Currently, the proportion of young teachers in teachers of industrial design is relatively large, most of them are a college graduate to enter, with a strong theoretical knowledge, but lack the necessary corporate design practice and perceptual knowledge, design capability is not enough. To solve this problem, one can hire design experts in famous schools, famous teachers, specialty important teachers to school part-time teaching, such as design teachers in Tsinghua University, Hunan University, Hefei University of Technology and other schools, or to school regularly to explain the guidance; another aspects, hire designers from design companies to part-time teaching in our school or consultant, the introduction of high-level business industry business representatives as a part-time teacher, absorption design director design industry design director, director, senior designer and the company's industrial design, planning and excellent designers such as part-time teachers, as industry representatives. The sharing of industrial design works: establish galleries, including the museum of outstanding works of industrial design, industrial design and technology museum and hall of industrial product model, teachers and students to visit at any time, the main showcase outstanding works abroad and graduate design and product structure anatomy, for undergraduate teach students and innovative, creative teaching. Designed to increase teachers' emotional and rational knowledge, skills and grasp the direction of design. The sharing of project task: participate in horizontal and vertical issues or projects, teachers can gain experience and improve the level of research. The sharing of internship training base: to industrial projects as a guide to create technical service platform as the goal, school and enterprise build a small batch production, high technology content ability of multifunctional alliance, outside campus productive training base, build a set of teaching and training, internships, employment in one of the campus, outside training practice base, share outstanding internship training base that between schools, between schools and businesses .

\subsubsection{The sharing of communication}

Promote "teacher practice posts": requires professional teachers with higher series design industry related certificates, improves the "Double Teachers" ratio. No less than two months per year train in practice post of enterprise. Regular "business part-time exercise": professional teachers exercise a part-time in cooperative enterprise at fixed period, and invite excellent enterprise designers to school to train for teachers, such as: design director in charge of the design, the project leader and the main designers.

Participate in "corporate real projects": requires professional teachers to participate in at least one of their actual projects' design, program production. Develop relevant incentives files; advocate establish a "professional industry open" and "teaching to the desired industry", "used by the students for the industry", "resource industry can do," the teaching reform ideas.

Communicate regularly: through the forms such as regular industrial design contest, industrial design teaching competition and the exchange Sharon of experiences between university teachers, build a varied forms and multi-channel communication platform, so that teachers in the field of design are professionals of new design concepts methods of research and design process, the collision sparks of 
wisdom, and constantly improve the professional teaching ability.

\subsection{The mechanisms of sharing}

\subsubsection{Encourage teachers to become graduate and Ph.D., study abroad to corporate training}

Professional competence of teachers to some extent determines the ability of teaching, The improvement of the ability of teaching staff indicates the improvement of the level of student learning to professional standards[6]. College intensify encourage young teachers to become graduate and $\mathrm{PhD}$, the teachers who get master's and doctoral degrees are granted in full reading fees and living expenses, wage subsidies do not buckle, research funding, the subject application, the promotion of priority, placement and other family members. University teacher training and education is an important part for young teachers to quickly adapt to the working environment, undertake research tasks, good teacher training and education work is an important task of teachers' construction, it is conducive to providing a learning environment for research teachers, encourage teachers to study abroad and to the enterprise corporate training, training abroad are all out with the cost of school, only to improve their theoretical and practical level of teachers, in order to build an excellent team of teachers as a whole.

\subsubsection{Establish a sharing mechanism to carry out the design practice}

Schools should unveil incentives and performance measures to encourage teachers of industrial design to practice more, practice skillfully and have the courage to practice. Industrial design is interdisciplinary, while improving teachers' theory, but also to strengthen the training of practical ability, focusing Combination [7]. Teachers in the profession continue to accept new knowledge, new ideas and new skills at the same time, the idea of changing the product, then the product into the industry, and finally generate economic benefits. Encourage teachers to participate in the development of practical projects, product design and reporting issues, to encourage teachers to use their spare time to the enterprise to carry out collaborative product development training, personally contact the latest technology and techniques, the design industry to keep abreast of the latest production levels and trends, practical experience.

\section{CONCLUSION}

The level of theory and practice of industrial design faculty is essential for building the industrial design profession. The quality of teachers is directly related to industrial design professional survival and development. Only by adhering to the teaching staff as the focus of the work, only the school and community resources and effective industrial design shared together, to take measures to effectively sharing mechanism, in order to effectively and actively promote industrial design faculty building.

\section{ACKNOWLEDGEMENT}

The work was supported by The Comprehensive Reform Pilot Project of Revitalization plan from Education Department of Anhui Province, Project Number: [2013zy088];

The Demonstration, Experiment and Training Center Project of Revitalization plan from Education Department of Anhui Province, Project Number: [2013sxzx025];

The Teaching and Reform Research Project of the Colleges of Anhui Province, Project Number: [2012jyxm591];

The Practice Education Base Project of Colleges and Enterprise Cooperation from Education Department of Anhui Province, Project Number: [2013jyxm588];

The Teaching and Reform Research Project of the Colleges of Anhui Province, Project Number: [2013zdjy158

\section{REFERENCES}

[1] Hui Yin.Exploring the building of the university's environment art design teaching staff. Art Science and Technology, 2013 (10):305-306.

[2] Yuting Han. Exploring the building of the university's environment art design teaching staff. Journal of Wanxi University, 2008 (4):44-47

[3] Kangmei Wang. Considerations about the building of the university's design teaching stafffrom quantitative to qualitative change. Popular Literature, 2013 (22):218

[4] Jun Zhang. Deciphering the phenomenon about $x+y=0$ in industrial design discipline. Art Science and Technology, 2014 (1):230

[5] Ping Xia, Lisha Zhou. Explore and analyse the building and countermeasures of the private colleges' art design teaching staff. Art Science and Technology, 2013 (10):1718.

[6] Hongbin Zhao, Zhenhong Zhao. Several issues ontraining the research-oriented teachersin colleges and universities. Journal of Liaoning University of Technology, 2009 (10):75-77.

[7] Hui Gao. Study on practical education of industrial design talenttraining.Design, 2014 (2):187-188. 